\title{
The human blood DNA methylome identifies crucial role of $\beta$-catenin in the pathogenesis of Kawasaki disease
}

\author{
Kuang-Den Chen ${ }^{1,2, *}$, Ying-Hsien Huang ${ }^{1}$, Mindy Ming-Huey Guo ${ }^{1}$, Tzu-Yang Lin ${ }^{2}$, \\ Wei-Teng Weng ${ }^{2}$, Hsiang-Jen Yang ${ }^{2}$, Kuender D. Yang ${ }^{3,4,5}$ and Ho-Chang Kuo ${ }^{1, *}$ \\ ${ }^{1}$ Department of Pediatrics and Kawasaki Disease Center, Kaohsiung Chang Gung Memorial Hospital and Chang Gung \\ University College of Medicine, Kaohsiung, Taiwan \\ ${ }^{2}$ Institute for Translational Research in Biomedicine, Liver Transplantation Center and Department of Surgery, Kaohsiung \\ Chang Gung Memorial Hospital and Chang Gung University College of Medicine, Kaohsiung, Taiwan \\ ${ }^{3}$ Department of Pediatrics, Mackay Memorial Hospital, Taipei, Taiwan \\ ${ }^{4}$ Institute of Biomedical Sciences, Mackay Medical College, New Taipei City, Taiwan \\ ${ }^{5}$ Institute of Clinical Medicine, National Yang-Ming University, Taipei, Taiwan \\ "These authors have contributed equally to this work \\ Correspondence to: Ho-Chang Kuo, email: erickuo48@yahoo.com.tw; dr.hckuo@gmail.com \\ Kuender D. Yang, email: yangkd.yeh@hotmail.com
}

Keywords: $\beta$-catenin; CD40; CD40 ligand; methylation; Kawasaki disease

Received: January 03, $2018 \quad$ Accepted: April 16, $2018 \quad$ Published: June 19, 2018

Copyright: Chen et al. This is an open-access article distributed under the terms of the Creative Commons Attribution License 3.0 (CC BY 3.0), which permits unrestricted use, distribution, and reproduction in any medium, provided the original author and source are credited.

\section{ABSTRACT}

Kawasaki disease (KD) is a type of acute febrile vasculitis syndrome and is the most frequent cause of cardiac illness in children under the age of five years old. Although the etiology of KD remains largely unknown, some recent genome-wide studies have indicated that epigenetic factors may be important in its pathogenesis.

We enrolled 24 KD patients and 24 non-KD controls in this study to access their DNA methylation status using HumanMethylation450 BeadChips. Another 34 KD patients and 62 control subjects were enrolled for expression validation. Of the 3193 CpG methylation regions with a methylation difference $\geq 20 \%$ between KD and controls, 3096 CpG loci revealed hypomehtylation, with only $3 \%$ being hypermethylated. Pathway buildup identified 11 networked genes among the hypermethylated regions, including four transcription factors: nuclear factor of activated T-cells 1, v-ets avian erythroblastosis virus E26 oncogene homolog 1, runt related transcription factor 3 , and retinoic acid receptor gamma, as well as the activator $\beta$-catenin. Ten of these network-selected genes demonstrated a significant decrease in mRNA in KD patients, whereas only CTNNB1 significantly decreased in correlation with coronary artery lesions in KD patients. Furthermore, CTNNB1-silenced THP-1 monocytic cells drastically increased the expression of CD40 and significantly increased the expression of both CD40 and CD40L in cocultured human coronary artery endothelial cells.

This study is the first to identify network-based susceptible genes of hypermethylated CpG loci, their expression levels, and the functional impact of $\beta$-catenin, which may be involved in both the cause and the development of KD. 


\section{INTRODUCTION}

A form of acute febrile systemic vasculitis, Kawasaki disease (KD) was first described by Kawasaki et al. in 1974 [1]; however, its origins are still generally unknown today. This disease affects children around the world, particularly those under the age of five years old. In general, KD patients clinically present with a prolonged fever for more than 5 days and have at least four of the following five major symptoms: diffuse mucosal inflammation, bilateral non-purulent conjunctivitis, cervical lymphadenopathy, indurative angioedema of the hands and feet, and polymorphous skin rashes, as was previously described [2]. The most serious complication arising from KD is coronary artery lesions (CAL), including myocardial infarction, coronary artery dilatation, coronary artery fistula, and coronary artery aneurysm [3]. In fact, KD is currently the leading cause of acquired heart disease in children in developed countries [4], and approximately $20-25 \%$ of untreated KD children develop coronary artery aneurysms.

While the exact origins of $\mathrm{KD}$ remain uncertain, growing evidence has suggested that the development of $\mathrm{KD}$ may be similar to an immune/autoimmune process [5]. Some researchers have suggested that KD may be prompted by an infectious agent in individuals with a genetic predisposition but not actually an infectious disease. Previous genome-wide association studies (GWAS) have shown that many genes are associated with susceptibility to KD, including FCGR2A [6], CD40 [7], BLK [8], and ITPKC [9]. The GWAS of various geographic areas had different results, with only CD40 and BLK being consistent in reports from both Japan and Taiwan. Environmental factors, epigenetic variants (FCGR2A), genetic factors, infectious agents, and lifestyle (such as the intake of food containing mercury), etc. have all been reported to be associated with $\mathrm{KD}$, thus suggesting that $\mathrm{KD}$ is a complex disease. Previous studies have found that epigenetic regulatory mechanisms are correlated with various diseases. Using data from our previous studies, we performed DNA methylation array using the Infinium HumanMethylation27 BeadChip array to evaluate the association between genomic hypomethylation of FCGR2A and the susceptibility to KD and intravenous immunoglobulin resistance [10]. The purpose of this study is to examine more detailed epigenetic changes in the susceptibility and pathogenesis of KD using HumanMethylation450 BeadChip, as well as to investigate potential mechanisms using a cell-cell interacting vasculitis model.

\section{RESULTS}

\section{DNA methylation dynamics in KD patients' peripheral blood}

We took peripheral blood samples from a total of 48 individuals (24 KD patients and 24 normal controls; see Table 1 upper panel) and subjected them to access DNA CpG methylation state using Infinium HumanMethylation450 BeadChips. This array consists of probes that determine the site-specific methylation status of more than $450 \mathrm{~K} \mathrm{CpG}$ loci across the human genome. In total, 1,703 genes were found distributed among 3,193 $\mathrm{CpG}$ regions (DMRs) with a methylation difference $\geq$ $20 \%$ between KD patients and normal control subjects (NC). Most DMRs were hypomethylated (3,096 target $\mathrm{CpG}$ loci) in the KD group, which corresponded to 1,664 imprinted genes, whereas only 3\% DMRs (97 CpG loci) were hypermethylated across 39 genes (Figure 1).

\section{Clusters of methylation signatures in KD with network-based gene enrichment analysis}

To improve the understanding of the biological context of the changes in the corresponding genes of DMRs in KD, 39 genes imposed on 97 hypermethylated loci and 1,664 genes imposed on 2,096 hypomethylated loci were additionally analyzed using Ariadne's pathway buildup for direct interaction and were further enriched using sub-network analysis (SNEA) to identify the respective putative networks. The enriched sub-networks, which included a set of single seed genes with target genes that correlated with the seed among these imprinted genes, were presented in a network layout, as shown in Figure 2, in which an enriched network containing 11 genes imposed on the rare hypermethylated regions in KD patients was connected. In a complex formed by the four transcription factors of nuclear factor of activated T-cells 1 (NFATC1), v-ets avian erythroblastosis virus E26 oncogene homolog 1 (ETS1), runt related transcription factor 3 (RUNX3), and retinoic acid receptor gamma (RARG), we considered the transcription activator $\beta$-catenin (CTNNB1) a core regulator in the sub-network, which normalizes both cell cycle progression and the severity of tissue inflammation. Table 2 (upper panel) shows the corresponding $\mathrm{CpG}$ regions identified using SNEA. However, we observed no significant gene-gene correlation with direct interaction among the abundant 1,664 genes imposed on the major hypomethylated regions in KD patients.

\section{Methylation status validation and expression levels of network-based hypermethylated genes in KD patients}

To validate the results from the network analysis, the methylation status of the aforementioned genes was detected using target-specific sequencing at $\mathrm{CpG}$ methylation sites pursuant to the array data via pyrosequencing. We validated 31 loci across the gene regions of the four major transcription regulators, as well as the cell cycle-related regulator cell division cycle 25B (CDC25B), the cardiac immune regulator programmed cell death 1 (PDCD1), and its three related effectors 
Table 1: Basal characteristics of patients with Kawasaki disease (KD) and control subjects

\begin{tabular}{lccc}
\hline Characteristics & KD Patients & Controls & $\boldsymbol{p}$-value \\
\hline Primary Set for M450 Array & & & - \\
Number of subjects & 24 & 24 & 0.778 \\
Male/Female & $13 / 11$ & $12 / 12$ & 0.401 \\
Age at study (years) & $1.91 \pm 1.52$ & $2.24 \pm 1.07$ & - \\
Age range & $0-7$ & $0-6$ & - \\
Validation Set & & & 0.882 \\
Number of subjects & $34^{\ddagger}$ & $32 / 30$ & 0.088 \\
Male/Female & $16 / 18$ & $2.46 \pm 1.95$ & - \\
Age at study (years) & $1.87 \pm 1.58$ & $0-10$ & \\
Age range & $0-7$ & & \\
\hline
\end{tabular}

The number included $13 \mathrm{CAL}$ and 21 non-CAL KD patients.

lymphotoxin $\alpha$ (LTA), B and T lymphocyte (BTLA), and CD247, of which 30 were found to be significantly hypermethylated among KD patients with * $\mathrm{p}<0.01$ (Table 2 , lower panel). We also studied the mRNA expression levels of the 10 network-associated genes with targeted re-sequencing by using next-generation sequencing technology, while the five transcription regulators NFATC1, ETS1, RUNX3, RARG, and CTNNB1 were also validated using quantitative RT-PCR in an independent validation set of subjects ( $n=34$ for $\mathrm{KD}, \mathrm{n}=62$ for $\mathrm{NC}$; see Table 1 lower panel). We adopted targeted RNA-Seq analysis to integrate next-generation sequencing and hybridization capture

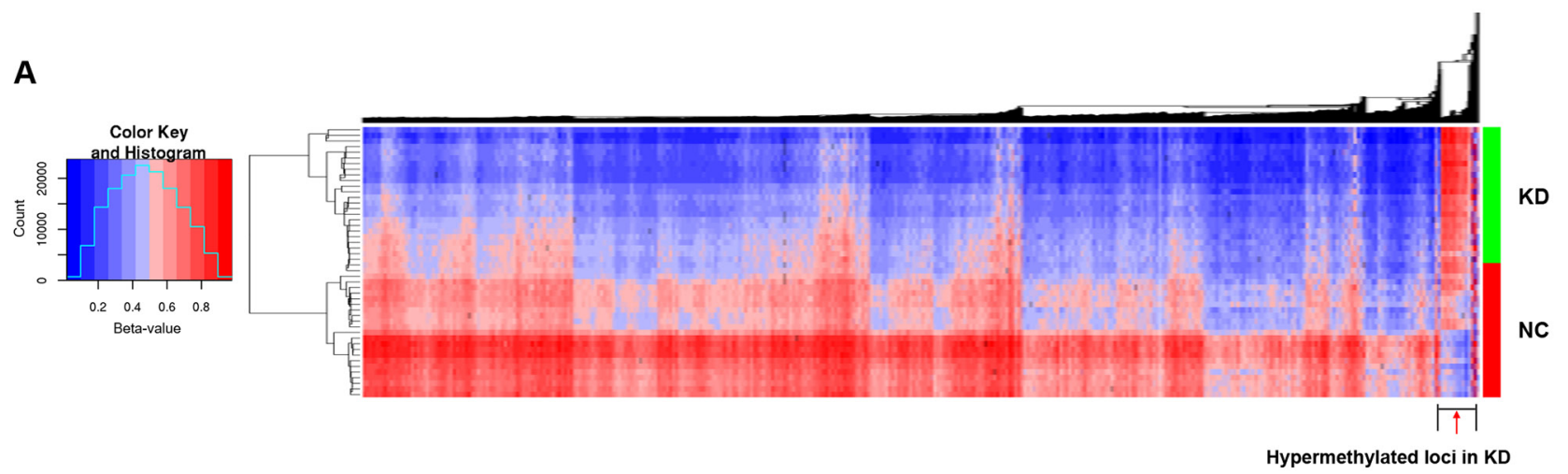

B
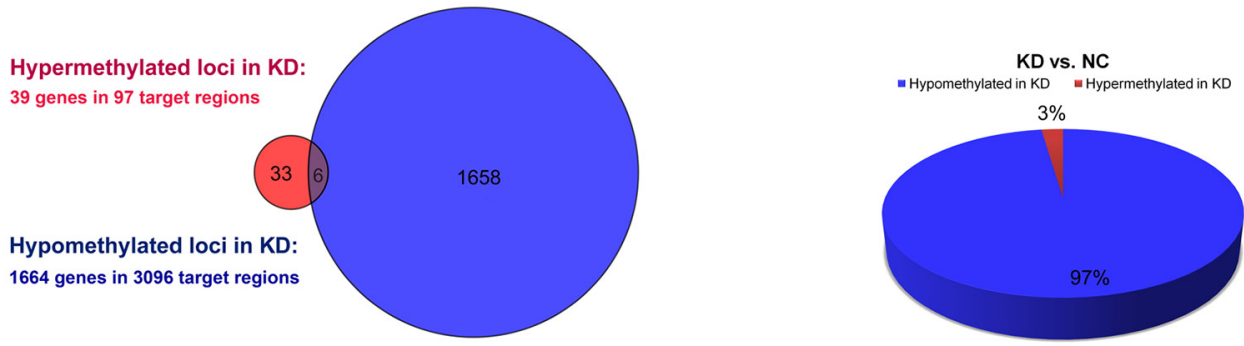

Figure 1: Differential methylation of individual CpG loci in peripheral blood. (A) Unsupervised two-way hierarchical clustering and heat map of genomic regions that include $\mathrm{CpG}$ di-nucleotides with a methylation difference of $\geq 20 \%$ found between 24 Kawasaki disease patients (KD) and 24 normal control subjects (NC). (B) The Venn diagram on the left shows the number of associated genes of hypermethylated $\mathrm{CpG}$ loci (red) and hypomethylated $\mathrm{CpG}$ loci (blue) in KD patients, with overlapping genes in purple; the pie chart on the right depicts the percentage of hypermethylated CpG loci (red) and hypomethylated CpG loci (blue) in KD patients. 
and performed oligonucleotide probes specific to the 11 selected genes using Illumina's standard protocols and substituting the molecular indexing adaptors for standard ligation adaptors, as was previously described in the Materials and Methods section. The results of the targeted mRNA sequencing demonstrated that 10 of the validated networked genes were considerably lower in KD patients compared to the normal control subjects $(\mathrm{p}<0.001$, Supplementary Table 1). Furthermore, Figure 3A shows that the mRNA levels of the five selected transcription regulators validated by RT-PCR were significantly decreased in KD patients, but only the $\beta$-catenin mRNA expression remained significantly lower in KD patients with coronary artery lesions (CAL) when compared to non-CAL KD patients (Figure 3B). Overall, the epigenetic data and reduced expression levels of CTNNB1, the associated TFs (NFATC1, ETS1, RUNX3, and RARG), the correlated regulators $\mathrm{CDC} 25 \mathrm{~B}$ and $\mathrm{PDCD} 1$, and the related effectors LTA, BTLA, and CD247 may indicate that they have pivotal roles and a unique importance with regard to susceptibility to KD, as well as its cardiac pathogenesis.

\section{CTNNB1 knockdown significantly increases the in vitro expression of CD40 in human premonocytic THP-1 cells and CD40L in co- cultivated HCAEC}

Researchers have previously indicated that the function of CD40 and CD40 ligand (CD40L) expression are correlated with KD susceptibility and the subsequent development of coronary artery lesions (CAL) [11]. To study the effects of $\beta$-catenin levels in monocytic cells, we knocked down $\beta$-catenin in a cultured THP-1 cell line using CTNNB1 siRNA for $24 \mathrm{~h}$ and treated it with $2 \mu \mathrm{g} /$ $\mathrm{mL}$ lipopolysaccharide (LPS) or PBS for another $24 \mathrm{~h}$, and then measured the protein levels of CD40 using Western blot analysis. THP-1 cells were grown to $60 \%$ confluence, followed by transfection with either human CTNNB1 siRNA (si-CTNNB1) or control siRNA (referred to as siRNC), as described in the Materials and Methods section. Protein lysates obtained from THP-1 cells after CTNNB1 knockdown showed a dramatic 10-fold suppression in total $\beta$-catenin protein compared to the normal control subjects (Figure 4A). Figure 4B demonstrates that the knockdown of both $\beta$-catenin and LPS increased the CD40 protein expression in THP-1 cells, and the combined treatment induced CD40 expression.

To investigate the effect of $\beta$-catenin-silenced THP1 on endothelial cells, we cocultured primary coronary artery endothelial cells (HCAEC) with transfected and/or LPS-treated THP-1 cells for another $8 \mathrm{~h}$, then washed out the suspended THP-1 cells, and analyzed the CD40 and CD40L expression in HCAEC. As shown in Figure 4C, $\beta$-catenin-silenced THP-1 largely increased both CD40 and CD40L expression in cocultured HCAEC. However, the up-regulation of CASP3 protein in HCAEC was only observed in cells cocultured with LPS-treated THP-1.

\section{DISCUSSION}

Dynamic epigenetic alterations, such as the methylation status of $\mathrm{CpG}$ sites in gene regulatory regions,

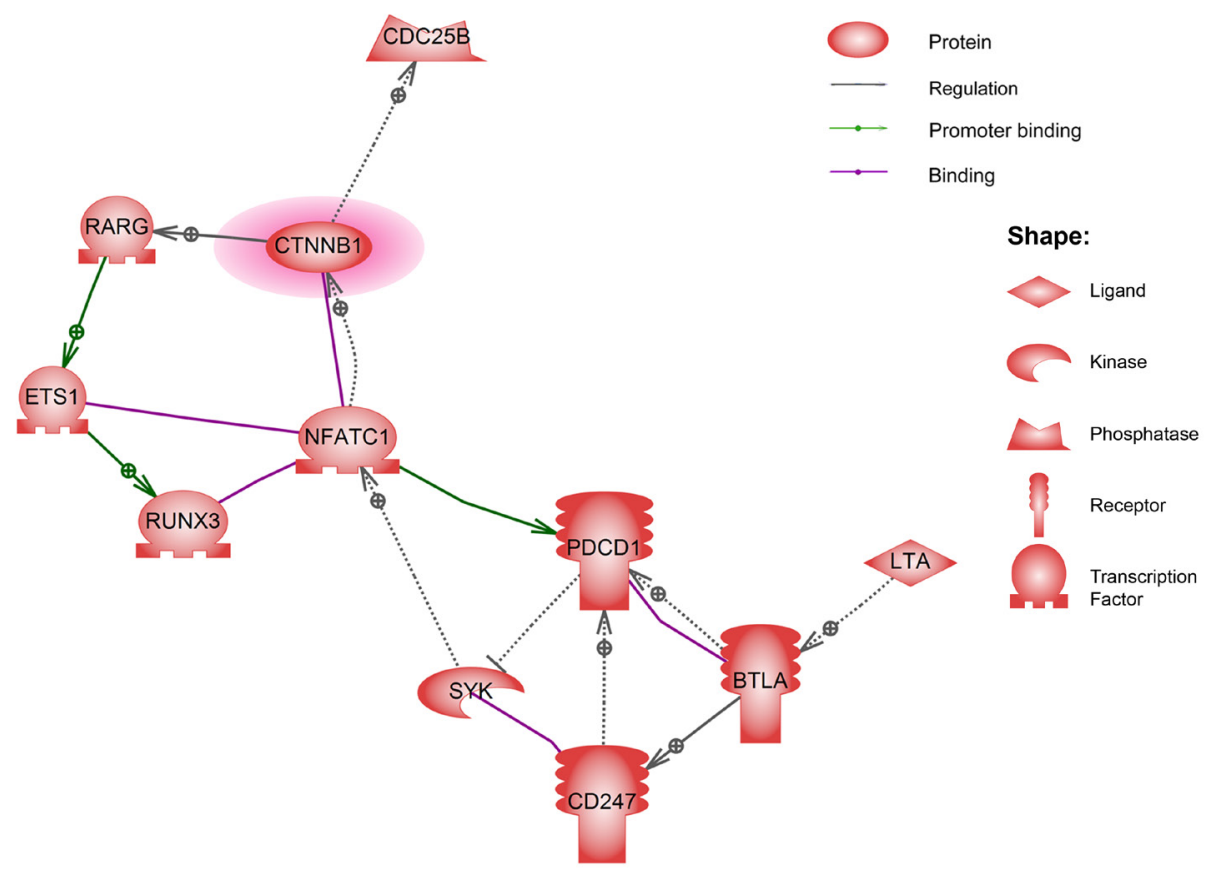

Figure 2: The direct interaction network of the genes identified from imprinting the hypermethylated regions in KD patients. 
Table 2: Hypermethylated CpG loci selected using network-based enrichment analysis and methylation levels (\%) that were technically validated by pyrosequencing in KD patients $(n=24)$ compared to normal control subjects $(\mathrm{NC}$; $n=24)$

\begin{tabular}{|c|c|c|c|c|c|c|}
\hline \multicolumn{7}{|c|}{ Hypermethylated CpG loci of network-enriched genes } \\
\hline CpG loci ID & Gene Symbol & Genomic Location & Strand & Functional Location & $\begin{array}{c}\text { Delta- } \\
\text { Beta }\end{array}$ & $p$-value \\
\hline $\operatorname{cg} 24157392$ & BTLA & $3: 113700663$ & $\mathrm{~F}$ & Body & 0.25195 & $1.60 \mathrm{E}-08$ \\
\hline $\operatorname{cg} 09032544$ & CD247 & $1: 165753919$ & $\mathrm{R}$ & Body & 0.31832 & $7.70 \mathrm{E}-04$ \\
\hline $\operatorname{cg} 07786657$ & & $1: 165754257$ & $\mathrm{R}$ & Body & 0.36159 & $5.60 \mathrm{E}-05$ \\
\hline $\operatorname{cg} 14165142$ & $\mathrm{CDC} 25 \mathrm{~B}$ & $20: 3726655$ & $\mathrm{R}$ & Body & 0.25253 & $1.10 \mathrm{E}-08$ \\
\hline $\operatorname{cg} 02737268$ & & $20: 3728182$ & $\mathrm{~F}$ & Body & 0.42308 & $1.90 \mathrm{E}-09$ \\
\hline $\operatorname{cg} 15421087$ & CTNNB1 & $3: 41215859$ & $\mathrm{~F}$ & TSS200 & 0.25553 & $3.20 \mathrm{E}-05$ \\
\hline $\operatorname{cg} 03295554$ & ETS1 & $11: 127900660$ & $\mathrm{~F}$ & Body & 0.26371 & $1.00 \mathrm{E}-05$ \\
\hline $\operatorname{cg} 26404422$ & & $11: 127872220$ & $\mathrm{~F}$ & Body & 0.26570 & $3.40 \mathrm{E}-04$ \\
\hline $\operatorname{cg} 26348243$ & LTA & $6: 31648440$ & $\mathrm{R}$ & 5'UTR & 0.28315 & $7.60 \mathrm{E}-04$ \\
\hline $\operatorname{cg} 14441276$ & & $6: 31647714$ & $\mathrm{R}$ & TSS1500;TSS200 & 0.25889 & $2.40 \mathrm{E}-06$ \\
\hline $\operatorname{cg} 02402436$ & & $6: 31648030$ & $\mathrm{~F}$ & TSS200;1stExon;5'UTR & 0.26393 & $1.70 \mathrm{E}-09$ \\
\hline $\operatorname{cg} 21999229$ & & $6: 31647993$ & $\mathrm{~F}$ & TSS200;1stExon;5'UTR & 0.26700 & $1.50 \mathrm{E}-05$ \\
\hline $\operatorname{cg} 16219283$ & & $6: 31647981$ & $\mathrm{~F}$ & TSS200;1stExon;5'UTR & 0.27092 & $9.00 \mathrm{E}-12$ \\
\hline $\operatorname{cg} 14597739$ & & $6: 31647977$ & $\mathrm{~F}$ & TSS200;1stExon;5'UTR & 0.28225 & $2.50 \mathrm{E}-08$ \\
\hline $\operatorname{cg} 17169196$ & & $6: 31648005$ & $\mathrm{~F}$ & TSS200;1stExon;5'UTR & 0.28398 & $6.90 \mathrm{E}-06$ \\
\hline $\operatorname{cg} 09621572$ & & $6: 31647952$ & $\mathrm{~F}$ & TSS200;1stExon;5'UTR & 0.33790 & $3.70 \mathrm{E}-10$ \\
\hline $\operatorname{cg} 14437551$ & & $6: 31647965$ & $\mathrm{~F}$ & TSS200;1stExon;5'UTR & 0.36865 & $5.10 \mathrm{E}-06$ \\
\hline $\operatorname{cg} 22324981$ & NFATC1 & $18: 75384481$ & $\mathrm{~F}$ & Body & 0.30353 & $4.00 \mathrm{E}-10$ \\
\hline $\operatorname{cg} 16308790$ & & $18: 75326961$ & $\mathrm{R}$ & Body & 0.28664 & $4.50 \mathrm{E}-06$ \\
\hline $\operatorname{cg} 03889044$ & PDCD1 & $2: 242450772$ & $\mathrm{~F}$ & TSS 1500 & 0.26858 & $3.10 \mathrm{E}-10$ \\
\hline $\operatorname{cg} 17322655$ & & $2: 242450800$ & $\mathrm{~F}$ & TSS1500 & 0.27499 & $1.90 \mathrm{E}-08$ \\
\hline $\operatorname{cg} 20805133$ & & $2: 242450865$ & $\mathrm{R}$ & TSS 1500 & 0.36842 & $6.60 \mathrm{E}-05$ \\
\hline $\operatorname{cg} 09993145$ & RUNX3 & $1: 25164492$ & $\mathrm{R}$ & TSS1500 & 0.38990 & 4.20E-04 \\
\hline $\operatorname{cg} 13461622$ & & $1: 25163972$ & $\mathrm{R}$ & 1stExon;5'UTR & 0.27998 & $2.20 \mathrm{E}-09$ \\
\hline $\operatorname{cg} 03961551$ & & $1: 25124317$ & $\mathrm{R}$ & Body & 0.29300 & 4.30E-06 \\
\hline $\operatorname{cg} 14054883$ & SYK & $9: 92659288$ & $\mathrm{R}$ & Body & 0.26680 & $1.60 \mathrm{E}-08$ \\
\hline $\operatorname{cg} 20059012$ & RARG & $12: 51899421$ & $\mathrm{~F}$ & Body & 0.27935 & $7.70 \mathrm{E}-07$ \\
\hline
\end{tabular}

Validation results of the methylation levels $(\%)$

\begin{tabular}{lcccccccc}
\hline \multirow{2}{*}{$\begin{array}{l}\text { Gene } \\
\text { Symbol }\end{array}$} & CpG loci & \multicolumn{9}{c}{ Methylation (\%) } & \multicolumn{2}{c}{ p-value } \\
\cline { 3 - 8 } & & \multicolumn{3}{c}{ NC (N=24) } & \multicolumn{2}{c}{ KD (N=24) } \\
\cline { 2 - 8 } & & Mean & SD & $\mathbf{9 5 \%}$ CI & Mean & SD & 95\% CI \\
\hline NFATC1 & 1 & 29.75 & 9.11 & $24.60-34.90$ & 49.79 & 8.34 & $46.45-53.13$ & $1,37 \mathrm{E}-6^{* * *}$ \\
& 2 & 27.27 & 8.22 & $22.51-31.82$ & 44.42 & 8.73 & $40.92-47.91$ & $3.01 \mathrm{E}-6^{* * *}$ \\
& 3 & 38.25 & 11.82 & $31.57-44.93$ & 63.17 & 9.55 & $59.35-66.99$ & $2.49 \mathrm{E}-6^{* * *}$
\end{tabular}

(Continued) 


\begin{tabular}{|c|c|c|c|c|c|c|c|c|}
\hline \multicolumn{9}{|c|}{ Validation results of the methylation levels (\%) } \\
\hline \multirow{3}{*}{$\begin{array}{l}\text { Gene } \\
\text { Symbol }\end{array}$} & \multirow[t]{3}{*}{ CpG loci } & \multicolumn{6}{|c|}{ Methylation (\%) } & \multirow[t]{3}{*}{ p-value } \\
\hline & & \multicolumn{3}{|c|}{$\mathrm{NC}(\mathrm{N}=\mathbf{2 4})$} & \multicolumn{3}{|c|}{$\mathrm{KD}(\mathrm{N}=\mathbf{2 4})$} & \\
\hline & & Mean & SD & $95 \% \mathrm{CI}$ & Mean & SD & $95 \% \mathrm{CI}$ & \\
\hline & 4 & 32.00 & 9.21 & $26.79-37.21$ & 52.94 & 8.51 & $49.55-56.36$ & $8.63 \mathrm{E}-7^{* * *}$ \\
\hline RUNX3 & & 29.75 & 7.98 & $25.24-34.26$ & 51.83 & 8.67 & $48.36-55.30$ & $4.00 \mathrm{E}-8^{* * *}$ \\
\hline ETS1 & & 39.17 & 15.07 & $30.64-47.69$ & 75.79 & 11.67 & $71.16-80.42$ & $4.05 \mathrm{E}-7^{* * *}$ \\
\hline \multirow[t]{7}{*}{ RARG } & 1 & 36.30 & 10.17 & $30.54-42.06$ & 50.20 & 11.30 & $45.68-54.72$ & $5.21 \mathrm{E}-4^{* *}$ \\
\hline & 2 & 32.81 & 13.17 & $25.36-40.26$ & 47.63 & 13.13 & $42.38-52.88$ & $2.13 \mathrm{E}-3^{*}$ \\
\hline & 3 & 35.96 & 12.34 & $28.98-42.94$ & 50.34 & 12.86 & $45.19-55.49$ & $1.77 \mathrm{E}-3^{*}$ \\
\hline & 4 & 21.75 & 6.42 & $18.11-25.38$ & 28.48 & 12.86 & $25.89-31.06$ & $3.61 \mathrm{E}-3^{*}$ \\
\hline & 5 & 20.78 & 7.52 & $16.52-25.03$ & 28.36 & 7.59 & $25.32-31.40$ & $4.70 \mathrm{E}-3^{*}$ \\
\hline & 6 & 29.55 & 10.54 & $23.58-35.51$ & 39.11 & 9.88 & $35.16-43.06$ & 8.05E-3* \\
\hline & 7 & 24.58 & 8.83 & $19.59-29.58$ & 36.80 & 7.42 & $33.83-39.77$ & $2.90 \mathrm{E}-4^{* *}$ \\
\hline CTNNB1 & & 3.67 & 1.30 & $2.93-4.40$ & 4.92 & 2.55 & $3.90-5.94$ & $1.00 \mathrm{E}-2^{*}$ \\
\hline \multirow[t]{8}{*}{ CDC25B } & 1 & 34.95 & 11.44 & $28.48-41.43$ & 59.75 & 11.73 & $55.05-64.44$ & $1.81 \mathrm{E}-6^{* * *}$ \\
\hline & 2 & 42.94 & 12.88 & $35.65-50.22$ & 72.23 & 12.79 & $67.11-77.34$ & $8.73 \mathrm{E}-7^{* * * *}$ \\
\hline & 3 & 47.26 & 8.22 & $42.60-51.91$ & 72.23 & 10.43 & $68.06-76.40$ & $9.17 \mathrm{E}-9^{* * *}$ \\
\hline & 4 & 45.03 & 7.85 & $40.58-49.47$ & 70.52 & 10.64 & $66.27-74.78$ & $3.07 \mathrm{E}-9^{* * *}$ \\
\hline & 5 & 47.15 & 8.34 & $42.43-51.86$ & 72.40 & 10.60 & $68.16-76.64$ & $9.78 \mathrm{E}-9^{* * * *}$ \\
\hline & 6 & 43.70 & 9.12 & $38.54-48.86$ & 66.58 & 12.52 & $61.57-71.58$ & $4.11 \mathrm{E}-7^{* * *}$ \\
\hline & 7 & 33.12 & 13.74 & $25.34-40.89$ & 49.73 & 16.84 & $42.99-52.47$ & $1.94 \mathrm{E}-3^{*}$ \\
\hline & 8 & 17.38 & 14.99 & $8.90-25.86$ & 23.58 & 12.42 & $18.61-28.55$ & 0.12 \\
\hline PDCD1 & & 35.25 & 11.84 & $28.55-41.95$ & 65.13 & 11.46 & $60.54-69.71$ & $1.82 \mathrm{E}-7^{* * *}$ \\
\hline \multirow[t]{4}{*}{ CD247 } & 1 & 72.50 & 16.42 & $63.21-81.79$ & 96.83 & 6.11 & $94.39-99.28$ & $1.44 \mathrm{E}-4^{* *}$ \\
\hline & 2 & 50.50 & 9.21 & $45.29-55.71$ & 76.04 & 12.10 & $71.20-80.88$ & $5.71 \mathrm{E}-8^{* * * *}$ \\
\hline & 3 & 53.83 & 9.85 & $48.26-59.41$ & 81.00 & 10.03 & $76.99-85.01$ & $4.29 \mathrm{E}-8^{* * *}$ \\
\hline & 4 & 54.08 & 9.09 & $48.94-59.23$ & 82.71 & 10.60 & $78.47-86.95$ & $4.03 \mathrm{E}-9^{* * *}$ \\
\hline \multirow[t]{2}{*}{ BTLA } & 1 & 61.33 & 11.79 & $54.66-68.00$ & 84.75 & 8.29 & $81.43-88.07$ & $5.77 \mathrm{E}-6^{* * *}$ \\
\hline & 2 & 58.75 & 10.97 & $52.54-64.96$ & 79.92 & 7.34 & $76.98-82.85$ & $8.37 \mathrm{E}-6^{* * *}$ \\
\hline \multirow[t]{2}{*}{ LTA } & 1 & 24.09 & 10.57 & $18.12-30.07$ & 42.29 & 12.83 & $37.15-47.42$ & $5.74 \mathrm{E}-5^{* * *}$ \\
\hline & 2 & 18.13 & 9.41 & $12.80-23.45$ & 34.04 & 10.85 & $29.69-38.38$ & $6.09 \mathrm{E}-5^{* * *}$ \\
\hline
\end{tabular}

The statistical significance: ${ }^{*}$-value $<0.01,{ }^{* *}$-value $<0.001,{ }^{* * *}$ p-value $<0.0001$.

are recognized as a part of various human diseases. In this study, we identified a global DNA hypomethylation pattern and specific network interactions of hypermethylated genes in KD by using the HumanMethylation 450 array at an increasing resolution. One of the most important signaling pathways, the wingless proteins $(\mathrm{Wnt}) / \beta$-catenin pathway, influences cell destiny, proliferation, migration, and differentiation and is vital to embryonic development and tissue homeostasis via epigenetic changes [12]. This pivotal signaling pathway also modulates the regenerative process in body systems $[13,14]$. Researchers have found that the $\mathrm{Wnt} / \beta$-catenin pathway is activated in response to heart injuries to promote cardiac repair [15] and plays a vital role in cardiac hypertrophy and remodeling during the heart's development $[16,17]$. In this study, we identified a cluster of $\beta$-catenin with four transcriptional 
regulators: RARG, ETS1, NFATC1, and RUNX3 from hypermethylated DMRs in KD patients. These genes were considerably decreased in the blood cells of KD patients. Nevertheless, the interpretation of $\beta$-catenin's function in KD pathogenesis may provide a clue about how the relatively few DMRs with hypermethylated $\mathrm{CpG}$ loci occurring among this cluster positively correlate with CAL symptoms among KD patients.

New evidence has shown that endothelial dysfunction caused by the vigorous development of immune responses is vital to the development of CAL in KD patients [18-20]. The interaction between CD40L and CD40 is critical for activating the immune system and enhancing pro-inflammatory cytokines and vascular endothelial cells' interaction with immune cells [21-23]. Our previous studies have also shown that an increased expression of CD40L on CD4 ${ }^{+}$T-cells correlated with susceptibility, CAL formation, and disease severity of $\mathrm{KD}$ [11]. In the current study, we found that knockdown of $\beta$-catenin on THP-1 significantly increases CD40 and CD40L expression in cocultured HCAEC. Off-target effects may play a role in the synthetic siRNA used for $\beta$-catenin silencing which lead to increased CD40 expression in THP-1 cells. Therefore, we verified the CTNNB1 gene silencing results on CD40 expression by using another siRNA product, which targets different positions in CTNNB1 transcript (sc-29209, purchased from Santa Cruz Inc.), and observed similar knockdown efficiency in reducing $\beta$-catenin protein expression that also significantly enhanced CD40 levels in THP-1 cells as well as CD40/CD40L expression in cocultivated HCAEC. Furthermore, the additive effect of $\beta$-catenin silencing and LPS on THP-1 for the HCAEC-expressed CD40L protein levels may be caused by activating parallel signaling pathways. LPS is an outer membrane molecule of Gram-negative bacteria and induces innate immune responses and pro-inflammatory polarization (M1) in macrophages through TLR4 signaling [24, 25]. M1 macrophages secrete inflammatory cytokines and are known to be the major source of reactive oxygen species (ROS) in atherosclerotic lesions that may accelerate disease progression by promoting atherogenic responses in endothelial and vascular smooth muscle cells $[25,26]$. Although M2 polarized macrophages represent an antiinflammatory phenotype and appear critical for balancing inflammation, a recent study found that intracellular nicotinamide phosphoribosyltransferase (iNAMPT) exerted anti-atherogenic effects on low-density lipoprotein receptor-deficient mouse model while its extracellular pro-inflammatory role has been widely studied in association with several metabolic and inflammatory disorders [27]. A previous Apo E-deficient mice study also demonstrated that the presence of both M1- and M2polarized macrophages in the arterial wall may contribute to distinct stages of inflammation in atherosclerotic plaque formation [28]. The results undoubtedly reflect the complexity of macrophage responses in aortic disease progression. CD40L (CD154) belongs to the tumor

A

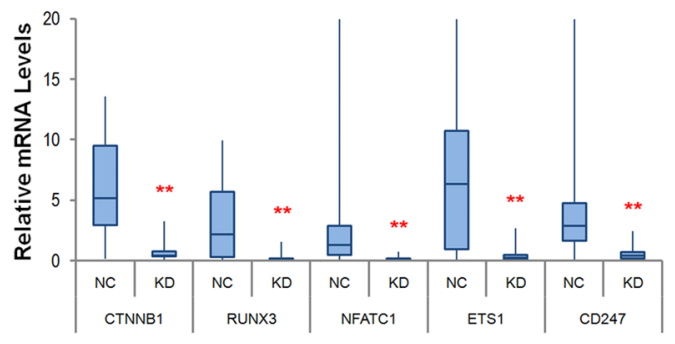

B

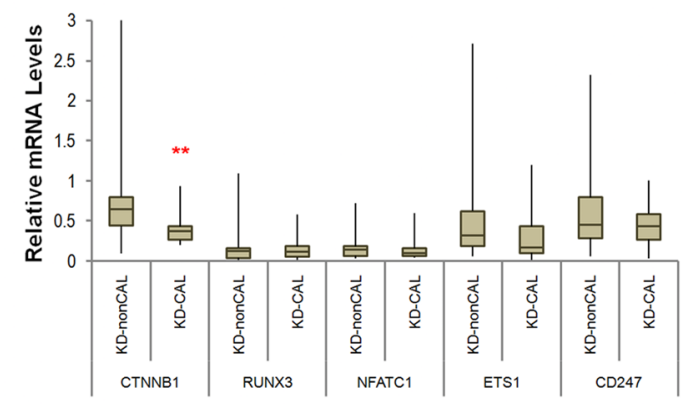

Figure 3: Box and whisker plots of the medium-level mRNA expression for the five network-based transcription regulators, measured using quantitative RT-PCR. (A) The mRNA levels of all five genes were considerably lower in KD patients $(\mathrm{n}=34)$ than in the normal controls $(\mathrm{NC}, \mathrm{n}=62)$; (B) Only the expression levels of $\beta$-catenin were significantly lower in KD patients with coronary artery lesions (CAL) when compared to non-CAL KD patients. ${ }^{* *} \mathrm{p}<0.005$ for each site according to the Mann-Whitney $U$ test. 
necrosis factor (TNF) superfamily, and the interaction with its receptor CD40 in a wide range of cell types in the vessel wall, thus leading to various inflammatory processes, has emerged as an important contributor to the inflammatory and atherogenic effects in vitro and in vivo [29-34]. CD40L has been shown to interact with CD40 on monocytes, macrophages, and endothelial cells, which induces intracellular signaling events, including the activation of mitogen-activated protein kinases (MAPKs), nuclear factor- $\kappa \mathrm{B}(\mathrm{NF}-\kappa \mathrm{B})$, and the subsequent expression

A

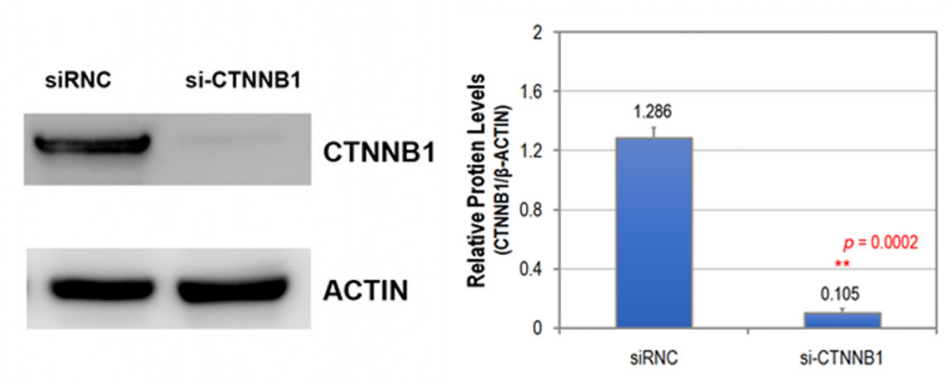

B

THP-1:

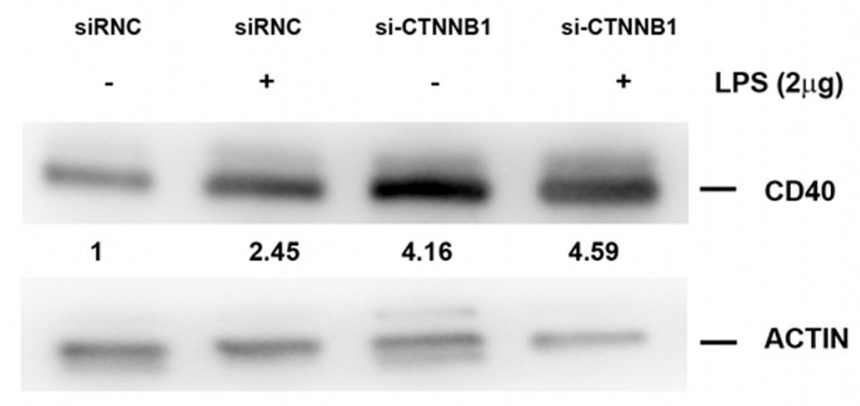

C

HCAEC/Treated THP-1 Co-culture (1:2):

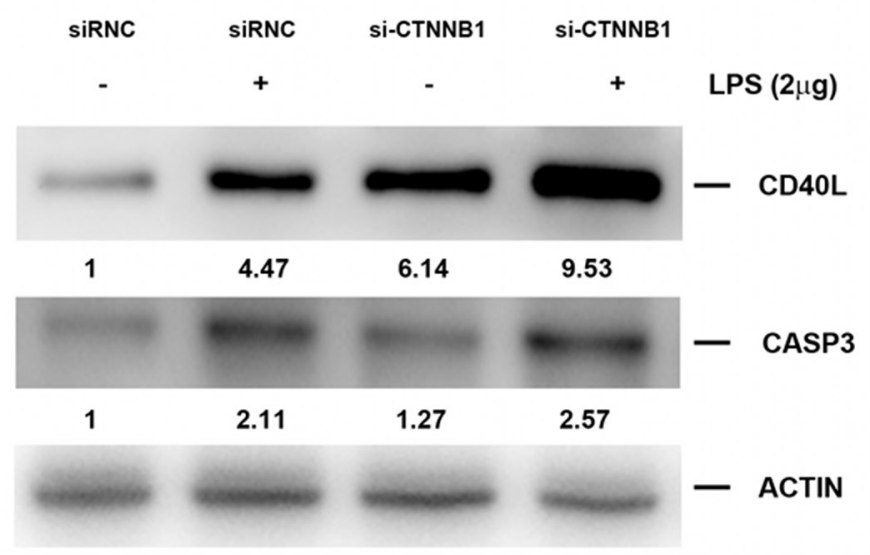

Figure 4: The knockdown of $\beta$-catenin on THP-1 considerably increases both CD40 and CD40L gene expression in cocultured endothelial cells. (A) The human monocytic cell line THP-1 was transfected with control siRNA (siRNC, 3 ng/ml) or $\beta$-catenin siRNA (si-CTNNB1, $3 \mathrm{ng} / \mathrm{ml}$ ) for $24 \mathrm{~h}$ and then harvested for Western blot analysis to evaluate the knockdown efficiency for the experiments. The expressed $\beta$-catenin protein determined by Western blot performed in triplicate. (B) The THP-1 monocytic cells were transfected with control siRNA (siRNC, $3 \mathrm{ng} / \mathrm{ml}$ ) or $\beta$-catenin siRNA (si-CTNNB1, $3 \mathrm{ng} / \mathrm{ml}$ ) for $24 \mathrm{~h}$ with control saline (-) or $2 \mu \mathrm{g} / \mathrm{ml}$ lipopolysaccharide (LPS) for another $24 \mathrm{~h}$ and then harvested for Western blot analysis. (C) THP-1 cells were initially transfected with control siRNA (siRNC, $3 \mathrm{ng} / \mathrm{ml}$ ) or $\beta$-catenin siRNA (si-CTNNB1, $3 \mathrm{ng} / \mathrm{ml}$ ) for $24 \mathrm{~h}$ and then exposed to saline (-) or LPS (+, $2 \mu \mathrm{g} / \mathrm{ml}$ ) for another $24 \mathrm{~h}$. Treated THP-1 cells were further added onto the cultured HCAEC with a ratio of 2:1 for another $8 \mathrm{~h}$ co-cultivating period. We measured the summary of the average density units under the blots in three independent experiments. 
of genes encoding IL-6, TNF $\alpha$, IL-8, inducible nitric oxide synthase (iNOS), and IL-12p40 [35-37]. CD40L has been shown to increase the expression of its receptor CD40 in endothelial cells, and some studies have indicated that the CD40L-induced CD40 expression contributes to endothelial dysfunction and vascular diseases $[38,39]$. Therefore, the increased expression of CD40 through $\beta$-catenin silencing in THP-1 could be the result of a secondary response via the paracrine effect of CD40L. Of particular note, the expression of CASP3 in HCAEC, which is another susceptible gene for $\mathrm{KD}$, was induced only by culturing LPS-treated THP-1, thus indicating a new mechanism through which endogenous suppression of $\beta$-catenin can additively enhance locoregional proinflammatory effects on innate immune cells and influence the pathogenic interaction with surrounding $\mathrm{ECs}$ in $\mathrm{KD}$ via epigenetic modulation. However, the role of $\beta$-catenin and its underlying mechanism with regard to CAL in KD still require additional research.

In this study, we also discovered the two associated regulators, $\mathrm{PDCD} 1$ and $\mathrm{CDC} 25 \mathrm{~B}$, and the three associated effectors, CD247, BTLA, and LTA, in SNEA, all of which interacted with the putative $\beta$-catenin-associated cluster and were also significantly hypermethylated in several promoter $\mathrm{CpG}$ loci; furthermore, their mRNA expressions were decreased in $\mathrm{KD}$. For the predicted regulator PDCD1, a co-inhibitory member of the CD28/CTLA-4 molecules expressed on lymphocytes, its role is to maintain the $\mathrm{T}$ cell unresponsiveness that is demonstrated in various experimental models of autoimmune and allergic inflammation [40-43]. The blockade of the programmed death receptor has been commonly researched and been found to exhibit enhanced rejection in transplants while promoting inflammation in various diseases, including stroke, vasculitis, encephalomyelitis, viral myocarditis, and atherosclerosis [44-51]. Of particular interest, PDCD1 has been observed as one of the genetic predispositions of KD-like features in PDCD1 knockout mice [52]. In the current study, we found that a specific regulatory region of PDCD1 was significantly hypermethylated in KD. This DMR, which ranges among the TSS1500 from the start codon of the PDCD1 gene, has also been observed in HIV-specific CD8 T cells, in which PDCD1 expression in prolonged virus exposure is increased [53]. This study is the first to reveal a correlation between PDCD1 down-regulation via epigenetic control and susceptibility to KD.

Furthermore, the identified effector CD247, also known as TCR/CD3-zeta, which encodes a transmembrane protein in the TCR complex, has been found to be responsible for the expression of inhibitory CTLA-4 molecules [54]. Defects in CD247 signaling result in deficient CTLA-4 expression and impaired $\mathrm{CD} 4^{+} \mathrm{CD} 25^{+}$Foxp 3 regulatory $\mathrm{T}$ cells. In this study, we discovered four significantly hypermethylated $\mathrm{CpG}$ loci on the $\mathrm{CD} 247$ promoter in $\mathrm{KD}$, which demonstrates a correlation between CD247 downregulation and susceptibility to $\mathrm{KD}$, that may be the result of DNA methylation. Moreover, we identified three hypermethylated $\mathrm{CpG}$ loci on the prompter region of the immune inhibitory receptor BTLA gene related to KD susceptibility. Taken together, our data indicates that the epigenetic down-regulation of BTLA, PDCD1, and CD247 in KD patients may enforce a poised impairment of immune suppression and exert a strong inflammatory storm in the organs. WNT signaling has been shown to be essential for $\mathrm{T}$ cell development in thymus [55-58], and the knockdown of $\beta$-catenin decreased $\mathrm{T}_{H} 2$ linage commitment and cytokine production in association with decreased GATA3 expression [59]. In our study, we also observed reduced GATA3 mRNA expression, as well as an increased proportion of $\mathrm{CD} 4{ }^{-\mathrm{CD}} 8 \mathrm{CD}^{-} 4^{+} \mathrm{T}$ lymphoid cells in the peripheral blood of KD patients (data not shown). The increase of double-negative $\mathrm{T}$ lymphoid cells implies that the epigenetic down-regulation of $\beta$-catenin may affect the development of early $\mathrm{T}$ cell commitment in $\mathrm{KD}$ patients. In $\mathrm{KD}$, vascular inflammation leads to the permanent damage of arteries, and the development of aneurysms is usually associated with macrophage accumulation, which also points towards a specific immune cell-endothelial cell interaction. A recent study demonstrated that serum from KD patients induced endothelial-to-mesenchymal transition (EndoMT) via suppression of the KLF4/miR-483 axis in primary human umbilical vein endothelial cells [60]. However, how the differential impacts of immune cells transmit acute inflammatory signals to vascular endothelial cells and cause persistent vessel wall abnormalities in $\mathrm{KD}$ require further research.

Therefore, the $\mathrm{CpG}$ locus and the expression levels of $\beta$-catenin may be pivotal in determining the disease severity of KD patients. Additional research into the underlying mechanism of the $\beta$-catenin-mediated signaling involved in the systemic cause and development of coronary artery injuries in KD is necessary and can potentially improve patient outcomes.

\section{MATERIALS AND METHODS}

\section{Participants}

The Institutional Review Board of the Chang Gung Memorial Hospital (No. 101-0680A3) approved this study, and we obtained informed consent from all of the participating children's parents or guardians. All participants were first given IVIG ( $2 \mathrm{~g} / \mathrm{kg})$ over a $12-\mathrm{h}$ period. We excluded any patients whose symptoms did not completely fit the diagnostic criteria of KD set forth by the American Heart Association, as in our previous studies $[18,61]$. This study also included blood samples from agematched non-KD control subjects (with no history of KD) for comparison. 


\section{DNA extraction and bisulfite conversion of genomic DNA (gDNA)}

In order to extract DNA, we first treated the collected blood cells with a $0.5 \%$ SDS lysis buffer and then with protease $\mathrm{K}(1 \mathrm{mg} / \mathrm{ml})$ for $4 \mathrm{~h}$ at $60^{\circ} \mathrm{C}$ to digest the nuclear protein. Complete genomic DNA was harvested using the Gentra extraction kit, followed by precipitation with $70 \%$ alcohol. NanoDrop ND-1000 (NanoDrop Technologies, Wilmington, DE, USA) was used to quantify $500 \mathrm{ng}$ of gDNA from each sample, followed by bisulfite conversion of the gDNA samples using the Zymo EZ DNA Methylation kit (Zymo Research Corporation, Orange, CA, USA). The bisulfite-converted gDNA was eluted and stored at $-20^{\circ} \mathrm{C}$ until ready for use.

\section{Genomic CpG methylation profiling}

Infinium HumanMethylation450 BeadChip (Illumina, San Diego, CA, USA) was used to carry out genome-wide DNA methylation patterns across 485,577 $\mathrm{CpG}$ loci. This panel was aimed at $96 \%$ of known CpG loci and included nearly all NCBI consensus coding sequence (CDS) genes. On average, $17 \mathrm{CpG}$ sites per gene were distributed across the $5^{\prime}$ flanking region of the transcription start sites TSS1500 and TSS200 (promoter), $5^{\prime}$ untranslated regions (UTR), first exon, gene body, and the 3'UTR. Additional specifications related to the array platform can be found online at http://support.illumina.com/array/array_kits/ infinium_humanmethylation450_beadchip_kit.html.

Bisulfate-converted DNA (BCD, $500 \mathrm{ng}$ ) was used per BeadChip for hybridization in accordance with the protocol and instructions of Infinium HD methylation. After completing the whole-genome amplification step and then controlled enzymatic end-point fragmentation, we precipitated and re-suspended the BCD samples for $16 \mathrm{~h}$ at $48^{\circ} \mathrm{C}$ for hybridization. During this process, the DNA molecules were annealed to two bead types with methylated loci (C)-specific and unmethylated loci (T)specific oligomers. Afterward, the non-hybridized or mis-hybridized DNA was washed away, followed by single-base extension using 2,4-dinitrophrnol- and biotinlabeled ddNTPs and the annealed BCD as templates. We then fluorescently stained and scanned the array and extracted the intensities of the beads using GenomeStudio methylation module (v.1.9.0) software.

The methylation score of the interrogated $\mathrm{CpG}$ locus was represented with a beta value that was determined according to the ratio of normalized probe intensity between methylated and unmethylated signals $(\mathrm{C} / \mathrm{C}+\mathrm{T})$. Beta values varied between 0 (unmethylated) and 1 (fully methylated). The average delta-beta values demonstrated the differential methylation between samples from KD patients and those from normal control subjects. The Pearson correlation coefficient was used as a distance metric to create the hierarchical clustering heat map of the differentially methylated probes in the Partek Genomic Suite (Partek Inc., USA).

\section{Pyrosequencing analysis}

We applied pyrosequencing to validate the methylation status by using a PyroMark Q24 instrument (Qiagen, Germany) and performed the subsequent quantification of methylation levels using its software (ver. 1.0.10). We prepared the BCD from $0.5 \mu \mathrm{g}$ genomic DNA using an EZ DNA methylation kit (Zymo Research) and then re-suspended it in $20 \mu \mathrm{l}$ of Tris buffer $(10 \mathrm{mM})$, which was then amplified by polymerase chain reaction (PCR) in the regions of interest with the PyroMark PCR kit (Qiagen, Germany) in accordance with the recommended protocol. Source sequences for the predesigned and customized pyrosequencing assays are provided in Supplementary Table 2. The sequencing results used to calculate the percentage of methylated cytosines at each given locus were analyzed using the previously described software [62].

\section{RNA isolation, targeted RNA-Seq, and quantitative RT-PCR}

Complete RNA from the white blood cells (WBC) of the participants was isolated using a FavorPrep Blood/ Cultured Cell Total RNA Mini kit (\#FABRK001-1, Favorgen Biotech Corporation, Ping-Tung, Taiwan). We targeted RNA-Seq using customized TruSeq Targeted RNA Expression Kits and MiSeq System from Illumina (San Diego, CA, USA). Both the sample preparation and the RNA-Seq procedure were performed pursuant to the manufacturer's instructions. The customized panel genes used in the TruSeq Targeted RNA Expression are listed in Supplementary Table 3. The quantitative RTPCR reaction was carried out with an ABI 7500 Fast Real-Time PCR System using the ABI TaqMan Fast Universal PCR master mix. Normalization was determined with human $\beta$-actin probe (ACTB, P/N: 4331128, ID: Hs01060665_g1). In order to detect expression level, we obtained the TaqMan probes for $\beta$-catenin (CTNNB1, P/N: 4331128, ID: Hs00355049 m1), NFATC1 (P/N: 4331128, ID: Hs00542678_m1), RUNX3 (P/N: 4331128, ID: Hs00231709_m1), ETS1 (P/N: 4331128, ID: Hs00428293 $\mathrm{m} 1$ ), and RARG (P/N: 4331128, ID: Hs01559234_m1) from Thermo Fisher Scientific. We verified the comparative RT-PCR data three times and calculated the fold increase using the comparative $2^{-\Delta \Delta \mathrm{Ct}}$ method.

\section{Cell cultivation and in vitro vasculitis model}

We grew human coronary artery endothelial cells (HCAEC) in an EGM-2 MV BulletKit (\#CC-3202, including basal medium [CC-3156], supplements, and 
growth factors [CC-4147], Lonza Group AG, Basel, Switzerland) at $37^{\circ} \mathrm{C}$ in a humid environment with $5 \%$ $\mathrm{CO}_{2}$. Human monocytic leukemia cells THP-1 were cultured in RPMI containing 10\% FCS, $100 \mathrm{U} / \mathrm{ml}$ penicillin and $100 \mu \mathrm{g} / \mathrm{ml}$ streptomycin at $37^{\circ} \mathrm{C}$ in $5 \% \mathrm{CO}_{2}$. For the experimental assays, we transfected cells using the GenMute siRNA Transfection Reagent (\#SL100568, SignaGen Laboratories, Rockville, MD, USA) with siRNA negative control (siRNC, 25nM) and CTNNB1 siRNA (10nM) from Sigma-Aldrich (St. Louis, MO, U.S.) according to the manufacturer's instructions.

For contact cocultivation of monocytes and endothelial cells, $2 \mathrm{~mL}$ aliquots of THP-1 cells $\left(1 \times 10^{6}\right.$ cells/well) were added to 6-well plates onto confluent HCAEC layers $\left(5 \times 10^{5}\right.$ cells/well $)$ in ECM. The ratio of the THP-1 cells and the HCAEC monolayer is 2:1 monocytes to ECs. We performed experiments with contact cocultures in the presence or absence of $2 \mu \mathrm{g}$ / $\mathrm{ml}$ Lipopolysaccharide (LPS) for $24 \mathrm{~h}$. To determine the role of suppressed CTNNB1 in monocyte-endothelial cell interactions, THP- 1 cells $\left(1 \times 10^{6}\right.$ cells $\left./ \mathrm{mL}\right)$ were transfected with CTNNB1 siRNA or control siRNA for $24 \mathrm{~h}$; HCAEC $\left(5 \times 10^{5}\right.$ cells $\left./ \mathrm{mL}\right)$ were directly cocultivated with THP-1 cells for $8 \mathrm{~h}$.

\section{Western blot analysis}

All proteins were homogenized with a loading buffer, separated by $10 \%$ SDS-PAGE, and transferred to nitrocellulose membranes, which were then probed overnight with primary antibodies at $4^{\circ} \mathrm{C}$ and incubated for 1 hour with respective conjugated secondary antibodies (1:2000, Cell Signaling Technology, Billerica, MA, USA). Immunoreactive proteins were visualized using ECL Western blotting detection reagents (Millipore) and quantitated using a G:BOX iChemi XL imaging system (J\&H Technology Co. Ltd.). The Western blotting reactivity of CTNNB1 ( $\beta$-catenin, sc-7199), CD40L (CD154, sc-978), CD40 (sc-975), and CASP3 (sc-7148) were measured using primary anti-human antibodies (Santa Cruz Biotechnology, Dallas, TX, USA) from lysates of siRNC-, CTNNB1 siRNA- transfected, and/or LPS-treated endothelial cells, respectively.

\section{Statistical analysis}

Continuous data are presented as median and range and compared among groups using the Mann-Whitney $U$ test. We performed statistical analysis using the SPSS software package for Windows (SPSS 15.0 for Windows; SPSS Inc., Chicago, IL, USA). To discover the molecular facts and biological context of the epigenetic changes, we analyzed data using Ariadne's Pathway Studio (Elsevier B.V., Amsterdam, Netherlands) to establish sub-network enrichment analysis with direct interactions. All p-values were derived from 2 -tailed tests, and a value of $<0.01$ was considered statistically significantly.

\section{Availability of array data}

All normalized and raw $450 \mathrm{~K}$ methylation array data were submitted to and are available in the Gene Expression Omnibus repository (GEO, Bethesda, MD, USA; accession GSE84624: http://www.ncbi.nlm.nih.gov/ geo/query/acc.cgi?acc=GSE84624).

\section{Author contributions}

K.-D. C. contributed to the experimental design, data analysis and interpretation, and writing of the manuscript, as well as experiments involving the cell-cell interacting vasculitis model; H.-C. K. contributed to the experimental design, data interpretation, and writing of the manuscript; K.-D. Y. contributed to the experimental design and data interpretation; Mindy M.-H. G. contributed to the experimental design and experiments involving the cellcell interacting vasculitis model; K.-S. H. contributed to all experiments involving DNA methylation arrays and pyrosequencing; W.-T. W. contributed to the experimental design and all experiments involving QRT-PCR and targeted RNA sequencing; T.-Y. L. and H.-J. Y. contributed to all experiments involving endothelial cells.

\section{ACKNOWLEDGMENTS}

This study received support from grants provided by the Ministry of Science and Technology (MOST: 105-2314-B-182A-037-MY2 and 105-2314-B-182-050MY3), the Ministry ofHealth and Welfare(PMRPG8E0011), and Chang Gung Memorial Hospital CMRPG8E0212 and CMRPG8F1911 to HC-K; CMRPG8F0561, CMRPG8F0562, CMRPG8D1021, CMRPG8D1022 and CMRPG8D1023 to KD-C) in Taiwan.

\section{CONFLICTS OF INTEREST}

All the authors hereby declare that they have no conflicts of interest to disclose related to this article.

\section{FUNDING}

All the authors hereby declare that they have no financial relationships to disclose related to this article.

\section{REFERENCES}

1. Kawasaki T, Kosaki F, Okawa S, Shigematsu I, Yanagawa H. A new infantile acute febrile mucocutaneous lymph node syndrome (MLNS) prevailing in Japan. Pediatrics. 1974; 54:271-6.

2. Kuo HC, Hsu YW, Wu MS, Chien SC, Liu SF, Chang WC. Intravenous immunoglobulin, pharmacogenomics, and Kawasaki disease. J Microbiol Immunol Infect. 2016; 49:1-7. https://doi.org/10.1016/j.jmii.2014.11.001. 
3. Burns JC, Glode MP. Kawasaki syndrome. Lancet. 2004; 364:533-44. https://doi.org/10.1016/S0140-6736(04)16814-1.

4. Rowley AH. Kawasaki disease: novel insights into etiology and genetic susceptibility. Annu Rev Med. 2011; 62:69-77. https://doi.org/10.1146/annurev-med-042409-151944.

5. Guo MM, Tseng WN, Ko CH, Pan HM, Hsieh KS, Kuo HC. Th17- and Treg-related cytokine and mRNA expression are associated with acute and resolving Kawasaki disease. Allergy. 2015; 70:310-8. https://doi.org/10.1111/all.12558.

6. Khor CC, Davila S, Breunis WB, Lee YC, Shimizu C, Wright VJ, Yeung RS, Tan DE, Sim KS, Wang JJ, Wong TY, Pang $\mathrm{J}$, Mitchell P, et al, and Hong Kong-Shanghai Kawasaki Disease Genetics Consortium, and Korean Kawasaki Disease Genetics Consortium, and Taiwan Kawasaki Disease Genetics Consortium, and International Kawasaki Disease Genetics Consortium, and US Kawasaki Disease Genetics Consortium, and Blue Mountains Eye Study. Genome-wide association study identifies FCGR2A as a susceptibility locus for Kawasaki disease. Nat Genet. 2011; 43:1241-46.

7. Lee YC, Kuo HC, Chang JS, Chang LY, Huang LM, Chen MR, Liang CD, Chi H, Huang FY, Lee ML, Huang YC, Hwang B, Chiu NC, et al. Two new susceptibility loci for Kawasaki disease identified through genomewide association analysis. Nat Genet. 2012; 44:522-5. https://doi.org/10.1038/ng.2227.

8. Onouchi Y, Ozaki K, Burns JC, Shimizu C, Terai M, Hamada H, Honda T, Suzuki H, Suenaga T, Takeuchi T, Yoshikawa N, Suzuki Y, Yasukawa K, et al. A genome-wide association study identifies three new risk loci for Kawasaki disease. Nat Genet. 2012; 44:517-21. https://doi.org/10.1038/ng.2220.

9. Onouchi Y, Gunji T, Burns JC, Shimizu C, Newburger JW, Yashiro M, Nakamura Y, Yanagawa H, Wakui K, Fukushima Y, Kishi F, Hamamoto K, Terai M, et al. ITPKC functional polymorphism associated with Kawasaki disease susceptibility and formation of coronary artery aneurysms. Nat Genet. 2008; 40:35-42. https://doi.org/10.1038/ng.2007.59.

10. Kuo HC, Chang JC, Kuo HC, Yu HR, Wang CL, Lee CP, Huang LT, Yang KD. Identification of an association between genomic hypomethylation of FCGR2A and susceptibility to Kawasaki disease and intravenous immunoglobulin resistance by DNA methylation array. Arthritis Rheumatol. 2015; 67:828-36. https://doi.org/10.1002/art.38976.

11. Wang CL, Wu YT, Liu CA, Lin MW, Lee CJ, Huang LT, Yang KD. Expression of CD40 ligand on CD4+ T-cells and platelets correlated to the coronary artery lesion and disease progress in Kawasaki disease. Pediatrics. 2003; 111: E140-7.

12. Aguilera O, Munoz A, Esteller M, Fraga MF. Epigenetic alterations of the Wnt/beta-catenin pathway in human disease. Endocr Metab Immune Disord Drug Targets. 2007; 7:13-21.

13. MacDonald BT, Tamai K, He X. Wnt/beta-catenin signaling: components, mechanisms, and diseases. Dev Cell. 2009; 17:9-26. https://doi.org/10.1016/j.devcel.2009.06.016.
14. Logan CY, Nusse R. The Wnt signaling pathway in development and disease. Annu Rev Cell Dev Biol. 2004; 20:781-810. https://doi.org/10.1146/annurev.cellbio.20.010403.113126.

15. Duan J, Gherghe C, Liu D, Hamlett E, Srikantha L, Rodgers L, Regan JN, Rojas M, Willis M, Leask A, Majesky M, Deb A. Wnt1/betacatenin injury response activates the epicardium and cardiac fibroblasts to promote cardiac repair. EMBO J. 2012; 31:429-42. https://doi.org/10.1038/emboj.2011.418.

16. Bergmann MW. WNT signaling in adult cardiac hypertrophy and remodeling: lessons learned from cardiac development. Circ Res. 2010; 107:1198-208. https://doi.org/10.1161/CIRCRESAHA.110.223768.

17. Gessert S, Kuhl M. The multiple phases and faces of wnt signaling during cardiac differentiation and development. Circ Res. 2010; 107:186-99. https://doi.org/10.1161/CIRCRESAHA.110.221531.

18. Kuo HC, Liang CD, Wang CL, Yu HR, Hwang KP, Yang KD. Serum albumin level predicts initial intravenous immunoglobulin treatment failure in Kawasaki disease. Acta Paediatr. 2010; 99:1578-83. https://doi.org/10.1111/j.1651-2227.2010.01875.x.

19. Yamakawa R, Ishii M, Sugimura T, Akagi T, Eto G, Iemura M, Tsutsumi T, Kato H. Coronary endothelial dysfunction after Kawasaki disease: evaluation by intracoronary injection of acetylcholine. J Am Coll Cardiol. 1998; 31:1074-80.

20. Furukawa S, Matsubara T, Motohashi T, Tsuda M, Sugimoto H, Yabuta K. Immunological abnormalities in Kawasaki disease with coronary artery lesions. Acta Paediatr Jpn. 1991; 33:745-51.

21. Li D, Liu L, Chen H, Sawamura T, Mehta JL. LOX-1, an oxidized LDL endothelial receptor, induces CD40/ CD40L signaling in human coronary artery endothelial cells. Arterioscler Thromb Vasc Biol. 2003; 23:816-21. https://doi.org/10.1161/01.ATV.0000066685.13434.FA.

22. Chatzigeorgiou A, Lyberi M, Chatzilymperis G, Nezos A, Kamper E. CD40/CD40L signaling and its implication in health and disease. Biofactors. 2009; 35:474-83. https://doi.org/10.1002/biof.62.

23. Pamukcu B, Lip GY, Snezhitskiy V, Shantsila E. The CD40CD40L system in cardiovascular disease. Ann Med. 2011; 43:331-40. https://doi.org/10.3109/07853890.2010.546362.

24. Freudenberg MA, Kalis C, Chvatchko Y, Merlin T, Gumenscheimer M, Galanos C. Role of interferons in LPS hypersensitivity. J Endotoxin Res. 2003; 9:308-12. https://doi.org/10.1179/096805103225002566.

25. Gordon S, Martinez FO. Alternative activation of macrophages: mechanism and functions. Immunity. 2010; 32:593-604. https://doi.org/10.1016/j.immuni.2010.05.007.

26. Orr AW, Hastings NE, Blackman BR, Wamhoff BR. Complex regulation and function of the inflammatory smooth muscle cell phenotype in atherosclerosis. J Vasc Res. 2010; 47:168-80. https://doi.org/10.1159/000250095. 
27. Bermudez B, Dahl TB, Medina I, Groeneweg M, Holm S, Montserrat-de la Paz S, Rousch M, Otten J, Herias V, Varela LM, Ranheim T, Yndestad A, Ortega-Gomez A, et al. Leukocyte overexpression of intracellular NAMPT attenuates atherosclerosis by regulating PPARgammadependent monocyte differentiation and function. Arterioscler Thromb Vasc Biol. 2017; 37:1157-67. https://doi.org/10.1161/ATVBAHA.116.308187.

28. Khallou-Laschet J, Varthaman A, Fornasa G, Compain C, Gaston AT, Clement M, Dussiot M, Levillain O, GraffDubois S, Nicoletti A, Caligiuri G. Macrophage plasticity in experimental atherosclerosis. PLoS One. 2010; 5: e8852. https://doi.org/10.1371/journal.pone.0008852.

29. Aukrust P, Waehre T, Damas JK, Gullestad L, Solum NO. Inflammatory role of platelets in acute coronary syndromes. Heart. 2001; 86:605-6.

30. Anand SX, Viles-Gonzalez JF, Badimon JJ, Cavusoglu E, Marmur JD. Membrane-associated CD40L and SCD40L in atherothrombotic disease. Thromb Haemost. 2003; 90:37784. https://doi.org/10.1160/TH03-05-0268.

31. Henn V, Slupsky JR, Grafe M, Anagnostopoulos I, Forster R, Muller-Berghaus G, Kroczek RA. CD40 ligand on activated platelets triggers an inflammatory reaction of endothelial cells. Nature. 1998; 391:591-4. https://doi.org/10.1038/35393.

32. Phipps RP. Atherosclerosis: the emerging role of inflammation and the CD40-CD40 ligand system. Proc Natl Acad Sci U S A. 2000; 97:6930-2.

33. Mach F, Schonbeck U, Sukhova GK, Bourcier T, Bonnefoy JY, Pober JS, Libby P. Functional CD40 ligand is expressed on human vascular endothelial cells, smooth muscle cells, and macrophages: implications for CD40-CD40 ligand signaling in atherosclerosis. Proc Natl Acad Sci U S A. 1997; 94:1931-6.

34. Karmann K, Hughes CC, Schechner J, Fanslow WC, Pober JS. CD40 on human endothelial cells: inducibility by cytokines and functional regulation of adhesion molecule expression. Proc Natl Acad Sci U S A. 1995; 92:4342-6.

35. Stout RD, Suttles J. The many roles of CD40 in cellmediated inflammatory responses. Immunol Today. 1996; 17:487-92.

36. van Kooten C, Banchereau J. CD40-CD40 ligand. J Leukoc Biol. 2000; 67:2-17.

37. Van Kooten C, Banchereau J. CD40-CD40 ligand: a multifunctional receptor-ligand pair. Adv Immunol. 1996; 61:1-77.

38. Chai H, Yan S, Wang H, Zhang R, Lin PH, Yao Q, Chen C. CD40 ligand increases expression of its receptor CD40 in human coronary artery endothelial cells. Surgery. 2006; 140:236-42. https://doi.org/10.1016/j.surg.2006.03.016.

39. Sakurai K, Cominacini L, Garbin U, Fratta Pasini A, Sasaki N, Takuwa Y, Masaki T, Sawamura T. Induction of endothelin-1 production in endothelial cells via co-operative action between CD40 and lectin-like oxidized LDL receptor (LOX-1). J Cardiovasc Pharmacol. 2004; 44: S173-80.

40. Probst HC, McCoy K, Okazaki T, Honjo T, van den Broek M. Resting dendritic cells induce peripheral CD8+ T cell tolerance through PD-1 and CTLA-4. Nat Immunol. 2005; 6:280-6. https://doi.org/10.1038/ni1165.

41. Cheng X, Zhao Z, Ventura E, Gran B, Shindler KS, Rostami A. The PD-1/PD-L pathway is up-regulated during IL-12-induced suppression of EAE mediated by IFN-gamma. J Neuroimmunol. 2007; 185:75-86. https://doi.org/10.1016/j.jneuroim.2007.01.012.

42. Francisco LM, Sage PT, Sharpe AH. The PD-1 pathway in tolerance and autoimmunity. Immunol Rev. 2010; 236:21942. https://doi.org/10.1111/j.1600-065X.2010.00923.x.

43. Boldison J, Chu CJ, Copland DA, Lait PJ, Khera TK, Dick $\mathrm{AD}$, Nicholson LB. Tissue-resident exhausted effector memory CD8+ T cells accumulate in the retina during chronic experimental autoimmune uveoretinitis. J Immunol. 2014; 192:4541-50. https://doi.org/10.4049/jimmunol.1301390.

44. Bodhankar S, Chen Y, Vandenbark AA, Murphy SJ, Offner H. PD-L1 enhances CNS inflammation and infarct volume following experimental stroke in mice in opposition to PD-1. J Neuroinflammation. 2013; 10: 111. https://doi.org/10.1186/1742-2094-10-111.

45. $\mathrm{Bu} \mathrm{DX}$, Tarrio M, Maganto-Garcia E, Stavrakis G, Tajima G, Lederer J, Jarolim P, Freeman GJ, Sharpe AH, Lichtman AH. Impairment of the programmed cell death-1 pathway increases atherosclerotic lesion development and inflammation. Arterioscler Thromb Vasc Biol. 2011; 31:1100-7. https://doi.org/10.1161/ATVBAHA.111.224709.

46. Carter LL, Leach MW, Azoitei ML, Cui J, Pelker JW, Jussif J, Benoit S, Ireland G, Luxenberg D, Askew GR, Milarski KL, Groves C, Brown T, et al. PD-1/PD-L1, but not PD-1/ PD-L2, interactions regulate the severity of experimental autoimmune encephalomyelitis. J Neuroimmunol. 2007; 182:124-34. https://doi.org/10.1016/j.jneuroim.2006.10.006.

47. Furukawa Y, Mandelbrot DA, Libby P, Sharpe AH, Mitchell RN. Association of B7-1 co-stimulation with the development of graft arterial disease. Studies using mice lacking B7-1, B7-2, or B7-1/B7-2. Am J Pathol. 2000; 157:473-84. https://doi.org/10.1016/S0002-9440(10)64559-2.

48. Kim KS, Denton MD, Chandraker A, Knoflach A, Milord R, Waaga AM, Turka LA, Russell ME, Peach R, Sayegh MH. CD28-B7-mediated T cell costimulation in chronic cardiac allograft rejection: differential role of B7-1 in initiation versus progression of graft arteriosclerosis. Am J Pathol. 2001; 158:977-86. https://doi.org/10.1016/S0002-9440(10)64044-8.

49. Ren X, Akiyoshi K, Vandenbark AA, Hurn PD, Offner H. Programmed death-1 pathway limits central nervous system inflammation and neurologic deficits in murine experimental stroke. Stroke. 2011; 42:2578-83. https://doi.org/10.1161/STROKEAHA.111.613182. 
50. Seko Y, Yagita H, Okumura K, Azuma M, Nagai R. Roles of programmed death-1 (PD-1)/PD-1 ligands pathway in the development of murine acute myocarditis caused by coxsackievirus B3. Cardiovasc Res. 2007; 75:158-67. https://doi.org/10.1016/j.cardiores.2007.03.012.

51. Zhang Y, Zhou Y, Lou J, Li J, Bo L, Zhu K, Wan X, Deng $X$, Cai Z. PD-L1 blockade improves survival in experimental sepsis by inhibiting lymphocyte apoptosis and reversing monocyte dysfunction. Crit Care. 2010; 14: R220. https://doi.org/10.1186/cc9354.

52. Chun JK, Jeon BY, Kang DW, Kim DS. Bacille Calmette Guerin (BCG) can induce Kawasaki disease-like features in programmed death-1 (PD-1) gene knockout mice. Clin Exp Rheumatol. 2011; 29:743-50.

53. Youngblood B, Noto A, Porichis F, Akondy RS, Ndhlovu ZM, Austin JW, Bordi R, Procopio FA, Miura T, Allen TM, Sidney J, Sette A, Walker BD, et al. Cutting edge: Prolonged exposure to HIV reinforces a poised epigenetic program for PD-1 expression in virus-specific CD8 T cells. J Immunol. 2013; 191:540-4. https://doi.org/10.4049/jimmunol.1203161.

54. Lundholm M, Mayans S, Motta V, Lofgren-Burstrom A, Danska J, Holmberg D. Variation in the $\mathrm{Cd} 3$ zeta (Cd247) gene correlates with altered T cell activation and is associated with autoimmune diabetes. J Immunol. 2010; 184:5537-44. https://doi.org/10.4049/jimmunol.0904012.

55. Staal FJ, Clevers HC. Wnt signaling in the thymus. Curr Opin Immunol. 2003; 15:204-8.

56. van de Wetering $\mathrm{M}$, de Lau W, Clevers H. WNT signaling and lymphocyte development. Cell. 2002; 109: S13-9.
57. Weerkamp F, Baert MR, Naber BA, Koster EE, de Haas EF, Atkuri KR, van Dongen JJ, Herzenberg LA, Staal FJ. Wnt signaling in the thymus is regulated by differential expression of intracellular signaling molecules. Proc Natl Acad Sci U S A. 2006; 103:3322-6. https://doi.org/10.1073/pnas.0511299103.

58. Staal FJ, Luis TC, Tiemessen MM. WNT signalling in the immune system: WNT is spreading its wings. Nat Rev Immunol. 2008; 8:581-93. https://doi.org/10.1038/nri2360.

59. Notani D, Gottimukkala KP, Jayani RS, Limaye AS, Damle MV, Mehta S, Purbey PK, Joseph J, Galande S. Global regulator SATB1 recruits beta-catenin and regulates $\mathrm{T}(\mathrm{H}) 2$ differentiation in Wnt-dependent manner. PLoS Biol. 2010; 8: e1000296. https://doi.org/10.1371/journal.pbio.1000296.

60. He M, Chen Z, Martin M, Zhang J, Sangwung P, Woo B, Tremoulet AH, Shimizu C, Jain MK, Burns JC, Shyy JY. miR-483 Targeting of CTGF Suppresses Endothelialto-Mesenchymal Transition: Therapeutic Implications in Kawasaki Disease. Circ Res. 2017; 120:354-365.

61. Kuo HC, Yang KD, Liang CD, Bong CN, Yu HR, Wang L, Wang CL. The relationship of eosinophilia to intravenous immunoglobulin treatment failure in Kawasaki disease. Pediatr Allergy Immunol. 2007; 18:354-9. https://doi.org/10.1111/j.1399-3038.2007.00516.x.

62. Colella S, Shen L, Baggerly KA, Issa JP, Krahe R. Sensitive and quantitative universal Pyrosequencing methylation analysis of CpG sites. Biotechniques. 2003; 35:146-50. 